\title{
The effect of pro-ecological procedures and plant injury on the content of free phenolic acids in winter wheat and on the feeding and development of Oulema melanopus
}

\author{
Robert Lamparski $^{1}$ (D) Karol Kotwica ${ }^{2} \cdot$ Daniel Modnicki $^{3} \cdot$ Maciej Balcerek $^{3} \cdot$ Beata Koim-Puchowska $^{4}$
}

Received: 17 March 2021 / Accepted: 10 September 2021 / Published online: 25 October 2021

(c) The Author(s) 2021

\begin{abstract}
Under laboratory conditions we have investigated the effect of the application of pro-ecological procedures (effective microorganisms and biostimulant Asahi SL) and plant injury on the production of free phenolic acids in winter wheat and on the feeding and development of Oulema melanopus. Wheat plants before reaching the BBCH 32 stage (the beginning of stem elongation) were treated with effective microorganisms and the biostimulant Asahi SL. Then, for 2 days, some of the plants were injured by $O$. melanopus and some were uninjured. The influence of factors was investigated in conditions under which the cereal leaf beetle had the possibility to choose their food (no-choice test or choice test). It was found that wheat plants produce on average $0.172 \% \mathrm{DM}$ of free phenolic acids. It has been shown that $O$. melanopus males and females preferred wheat previously uninjured. Also, irrespective of whether the plants were previously injured or uninjured, the females of that pest species always that caused areally more extensive leaf losses than the males. Treating plants with effective microorganisms and biostimulant Asahi SL is a secondary factor, as compared to previous wheat injury. Additionally, in choice tests, both males and females $O$. melanopus much preferred feeding on plants unprovided with preparations, whereas in no-choice tests, the application of pro-ecological procedures does not reduce egg laying by pests, does not adversely affect embryogenesis length and does not reduce hatching $\mathrm{L}_{1}$.
\end{abstract}

Keywords Free phenolic acids · Oulema melanopus $\cdot$ Plant injury $\cdot$ Effective microorganisms $\cdot$ Biostimulant Asahi SL

\section{Introduction}

In their natural habitat, as well as emitting volatile organic compounds (VOC), plants show various compositions of secondary metabolites with allelopathic effects (Harborne 1997). One of the most active groups of so-called allelo compounds taking part in environmental interactions is that of phenolic compounds. They are common in plant tissues and reveal a toxic effect even at a range of low concentrations (Li et al. 2010). Their structures include aromatic rings substituted with hydroxyl groups. Often, phenolic compounds create bonds with proteins, carbohydrates (glycosides), alkaloids or terpenoids in plant tissues (Leszczyński 2010). The primary job of phenolic compounds is to inhibit the activity

Handling Editor: Heikki Hokkanen.

Robert Lamparski

robert@pbs.edu.pl

Extended author information available on the last page of the article of enzymes, especially oxidoreductases and hydrolases. A high content of phenols is usually accompanied by an increased content of peroxidases and oxidases, which result in the accumulation of high amounts of polyphenols and quinones, which in turn exhibit strong antibiotic properties in animals (Ciepiela and Chrzanowski 2000). Furthermore, phenolic compounds reveal strong antibacterial and antifungal properties (Shi et al. 2011). They can also inhibit cell divisions, longitudinal root increase and trigger changes in cell ultrastructure, thus disturbing the adequate growth and development of the entire plant ( $\mathrm{Li}$ et al. 2010).

One of the key properties of plant allelo compounds is the antifeedant effect. The compounds limit the growth and development of insects, and affect their behavior (Mallikarjuna et al. 2004; Smith and Boyko 2007; Cipollini et al. 2008). Such properties of phenolic compounds result in serious disorders in the food chains found in a specific environment. This is a result of the digestion process being disturbed by those substances, often combined with an irritation of digestive system walls in herbivores, which, 
consequently, significantly decreases the digestibility of the food uptaken (Leszczyński 2010). Numerous groups of derivatives of phenolic compounds formed in the metabolic pathway of shikimic acid are known to prevent insect feeding. The most important ones-flavonoids (including tannins), phenolic glycosides, e.g., coumarin - are also essential. Other shikimate pathway derivatives include also other phenolic compounds, including alcohols and phenolic acids, phenylpropanoids and tannins (Bennett and Wallsgrove 1994; Malinowski 2008; Leszczyński 2010).

Phenolic acids are common in the world of plants. These compounds show a varied chemical structure and various properties. Characteristic is the presence of hydroxyl and carboxyl groups. Depending on the chemical structure (number of carbon atoms in the side chain), the derivatives of cinnamic and benzoic acids are found (Gawlik-Dziki 2004; Mróz et al. 2012). In plants, phenolic acids occur in two forms: bound or free. In the bound form they act as components of lignins and hydrolysable tannins, esters, glycosides, flavonoids, fatty acids, sterols as well as polymers of cell walls, whereas free phenolic acids are formed from a breakdown of bonds in the process of hydrolysis (Breinholt 1999; Michalski and Horoszkiewicz-Janka 2005; Klepacka and Fornal 2006, 2008; Jeszka et al. 2010).

Those plant defense strategies are naturally developed systems that have evolved for many generations. Humans have been trying to use different actions to "support" the plants against attack by pests. The interest of agricultural practitioners and, in Poland, the green policy of socalled "production biologization", encourage a search for, non-industrial, yield-protecting and yield-forming agents enhancing mostly the biodiversity of agrobiocenoses and plant resistance (Dzienia et al. 2006; Piskier 2006; Kotwica et al. 2011), including effective microorganisms (EM) and the biostimulant Asahi SL (BA). Those pro-ecological procedures, which are alternatives to the chemical method, increase plant resistance to biotic and abiotic stress factors. They are known for enhancing plant health status, yield and soil properties to more favor the growth and development of crop species and to enhance resistance to rainfall deficit (Piskier 2006; Maciejewski et al. 2007; Kaczmarek et al. 2008; Okorski and Majchrzak 2008; Janas 2009; Truba et al. 2012).

The beneficial effects of EM on soil properties, plant growth and the number of harmful organisms, including insect pests, are known. These beneficial effects thus reduce the negative effects of the cultivation simplifications in plant monoculture, while limiting the pressure of chemical products (used in plant protection) on the environment (Douglas 2007; Javaid and Shah 2010; Javaid and Bajwa 2011; Megali et al. 2015). These microorganisms can regulate hormone signaling including the jasmonic acid and ethylene and salicylic acid pathways, thereby leading to gene expression, biosynthesis of secondary metabolites, plant defensive proteins and different enzymes and volatile compounds that may induce defenses against pest insects (Rashid and Chung 2017). Also the foliar application of plant resistance biostimulators increases the resistance of the agroecosystem to stress factors (Piskier 2006).

Asahi SL and other biostimulants applied externally strengthen plant cell walls, enhance the effect of auxins, participate in nitrogen metabolism and cytoplasm transportation, stimulate blooming, increase plant resistance to water and thermal stress, and improve the ability of plants to reconstruct mechanical damage and protect themselves against pathogenic infections. They allow plants to adapt more quickly to changeable environmental conditions and reduce the growth of some pathogenic fungi, and consequently, they contribute to the increase in plant productivity (Černy et al. 2002; Czeczko and Mikos-Bielak 2004; Harasimowicz-Hermann and Borowska 2006; Matysiak et al. 2011).

Cereal plants under field conditions are exposed to attack from a wide range of phytophagous entomofauna. The most important of them are cereal leaf beetles (Oulema melanopus L. and Oulema gallaeciana Heyden) and many cereal aphids. Cereal leaf beetle feeds on numerous species of grasses and is considered a major pest of oats, barley and wheat. Several methods are used to combat them, including chemical, agrotechnical and biological methods (Kaniuczak and Bereś 2008; Philips et al. 2011).

The primary aim of this study has been to determine the content of free phenolic acids in winter wheat provided with EM and BA and the effect of previous plant injury by pests and to correlate the data with the extent of $O$. melanopus (L.) feeding and development. The data will specify the role of those factors in modifying pest feeding behaviour.

\section{Materials and methods}

\section{Experimental procedure}

Our study was performed in 2013 and 2014 at the laboratory of the Department of Biology and Plant Protection, UTP University of Science and Technology, Bydgoszcz, Poland and the Department of Pharmacognosy, Nicolaus Copernicus University, Bydgoszcz, Poland $\left(53^{\circ} 07^{\prime} \mathrm{N}\right.$ and $\left.18^{\circ} 00^{\prime} \mathrm{E}\right)$ and was part of our research project, which was carried out in field and laboratory conditions.

Each year of laboratory tests began with the import of soil from a field from an individual farm in the Kruszwica community-Kuyavian-Pomeranian Voivodeship, Poland $\left(52^{\circ} 61^{\prime} \mathrm{N} ; 18^{\circ} 44^{\prime} \mathrm{E}\right)$. A detailed description of all the performed agrotechnical activities, fertilization and pest control treatments are given in Lamparski (2020). In the 
spring of 2013 and 2014, two different types of soil were imported to the laboratory (incorporated with the stubbles from the previous crop), where: (1) EM was introduced into the soil during post-harvest cultivation in autumn 2012 and 2013 and (2) EM was introduced into the soil during post-harvest cultivation in autumn 2012 and 2013.

In the laboratory, in 2013 and 2014, from the 3rd week of March until mid-April, winter wheat (Triticum aestivum L., cultivar Arktis) was sown in pots $(\varnothing=13 \mathrm{~cm}, 10 \mathrm{~cm}$ high). In each pot, ten seeds were sown $2.5-3.0 \mathrm{~cm}$ deep.

The effect of the application of nine levels the EM and $\mathrm{BA}$ in winter wheat cultivation was investigated: $1 \times \mathrm{EM}+1 \times \mathrm{BA} ; 1 \times \mathrm{EM}+2 \times \mathrm{BA} ; 1 \times \mathrm{EM}+0 \times \mathrm{BA}$; $2 \times \mathrm{EM}+1 \times \mathrm{BA} ; 2 \times \mathrm{EM}+2 \times \mathrm{BA} ; 2 \times \mathrm{EM}+0 \times \mathrm{BA}$; $0 \times \mathrm{EM}+1 \times \mathrm{BA} ; 0 \times \mathrm{EM}+2 \times \mathrm{BA}$ and control- $0 \times \mathrm{EM}+0 \times \mathrm{BA}$ ). Treatments, dose, method and time of application are shown in Table 1.

The commercial product: EM Naturalnie Aktywny is a concentrate of effective microorganisms that improves soil fertility. It has the PZH/HT-1448/2002 certificate and IUNG qualification certificate No. NE/1/2004. EM is a safe product for people, animals and the environment. The composition specified on the packaging is: lactic acid bacteria, photosynthetic bacteria, yeast, cane molasses and Azotobacter. It does not contain genetically modified components (GMO). It is manufactured under license from EMRO-EM Research Organization Japan.

Biostimulant Asahi SL is a stimulator of growth and yielding of plants in the form of a liquid for dilution with water. The description of operation there is in the annex to the decision of the Ministry of Agriculture and Rural Development No. R-357/2010d of 27.12.2010. It contains the active substances (compounds from the group of nitrophenol derivatives): sodium para-nitrophenolate $(0.3 \%)$, sodium ortho-nitrophenolate $(0.2 \%)$ and sodium 5 -nitroguayacolate $(0.1 \%)$. The shelf life of the product is 3 years. It is permissible to use the product in the cultivation of agricultural, vegetable and fruit crops.

During the plant growth, $140 \mathrm{~kg} \cdot \mathrm{N} \cdot \mathrm{ha}^{-1}, 30 \mathrm{~kg}$ $\mathrm{P}_{2} \mathrm{O}_{5} \cdot \mathrm{ha}^{-1}$ and $60 \mathrm{~kg} \mathrm{~K} \mathrm{~K}_{2} \mathrm{O} \cdot \mathrm{ha}^{-1}$ were applied i.e. $0.1858 \mathrm{~g} \mathrm{~N}, 0.0398 \mathrm{~g} \mathrm{P}_{2} \mathrm{O}_{5}$ and $0.0796 \mathrm{~g} \mathrm{~K}_{2} \mathrm{O}$ per pot. The plants were irrigated weekly with $100 \mathrm{ml}$ of water per pot and grown in the air-conditioned room $\left(21 \pm 1{ }^{\circ} \mathrm{C}, \mathrm{L} 16\right.$ :D8 photoperiod and 70\% Relative Humidity).

\section{Laboratory tests}

7 weeks after sowing, the plants reached the $\mathrm{BBCH}-32$ stage (beginning of stem elongation). On half of the plants, in a Petri dish $(\varnothing 10 \mathrm{~cm})$, the end segment of the top leaf of each wheat plant was placed with a pair of adults of cereal leaf beetle (sex differentiation-in copula). After 2 days, the insects were removed. All plants (injured or not) were used for the following laboratory tests:

(1) Determination of free phenolic acids production in plants provided with EM and BA (wheat previously injured or not).

Plants injured by $O$. melanopus and uninjured were cut at soil level with scissors, weighed and dried at $32{ }^{\circ} \mathrm{C}$ for 2 days. The dried, weighed and ground plants were subjected to tests with three replications. Free phenolic acids were assayed with the spectrophotometric method, Arnova (Pharmacopoeia Polonica 2011). Absorbance was measured with a UV-Vis spectrophotometer (Hitachi U-2900, Japan), $X=490 \mathrm{~nm}$. All the solvents were purchased from POCH (Gliwice, Poland). The content of free phenolic acids was assayed as converted into caffeic acid. Two weighed portions were selected from each wheat plant sample. The extract was made from each portion and then base solution was made from which three test solutions and one reference solution were prepared. The content of free phenolic acids was given in \% of dry matter (DM) of the plant material.

(2) No-choice test-determine O. melanopus male and female feeding on plants provided with EM and BA (wheat previously injured or not).

3 days after cereal leaf beetle feeding, the lengths of leaf injuries made by a single pair of cereal leaf beetles at imaginal stage were measured and compared (sexual dimorphism-in copula). The results were presented as the total feeding scar length $[\mathrm{mm}]$ on a the 5-cm-long leaf caused by one female or one male of $O$. melanopus adults within a
Table 1 Treatments, dose, method and time of application

\begin{tabular}{llll}
\hline Treatment & Dose (kg/ha), application method & Date applied & Growth phase \\
\hline $1 \times$ EM & $40 \mathrm{~kg} / \mathrm{ha}$, applied to soil & $14.08 .2012,16.08 .2013$ & Before sowing \\
$2 \times \mathrm{EM}$ & $20 \mathrm{~kg} / \mathrm{ha}$, applied to soil & $14.08 .2012,16.08 .2013$ & Before sowing \\
& $20 \mathrm{~kg} / \mathrm{ha}$, applied to leaves & $23.04 .2013,28.04 .2014$ & $\mathrm{BBCH} 21$ \\
$1 \times \mathrm{BA}$ & $1.0 \mathrm{~kg} / \mathrm{ha}$, applied to leaves & $25.04 .2013,30.04 .2014$ & $\mathrm{BBCH} 21$ \\
$2 \times \mathrm{BA}$ & $0.5 \mathrm{~kg} / \mathrm{ha}$, applied to leaves & $25.04 .2013,02.05 .2013$ & BBCH 21 \\
& $0.5 \mathrm{~kg} / \mathrm{h}$, applied to leaves & $30.04 .2014,05.05 .2014$ & BBCH 28 \\
\hline
\end{tabular}


period of 1 day (Clement et al. 2011). The experiments were made in five replications.

(3) No-choice test-determine O. melanopus development on plants provided with EM and BA (wheat previously uninjured).

To evaluate the effect of the pro-ecological procedures on egg laying, one pair of beetles was placed on Petri dishes for 3 days, the eggs laid were counted and the results were given as the number of eggs per pair. The effects of the preparations on the embryogenesis length [days] and the number of hatched larvae phase 1 , expressed as \%, were also studied. The experiments were made in five replications.

(4) Choice test-comparison O. melanopus male and female feeding on plants provided with EM and BA or not (wheat previously uninjured).

The pots with plants were provided with racks on which plastic Petri dishes (10 $\mathrm{cm}$ in diameter) were placed. Inside the dish, in the middle, at the bottom side, with a little piece of transparent tape, two end sections of top plant leaves were fixed $2 \mathrm{~cm}$ away. Then, two insects were placed inside. After 3 days the insects were removed and leaf injuries were counted. The results were presented as the total feeding scar length [mm] on the 5-cm-long leaves caused by one female or one male $O$. melanopus adult within a period of 1 day. The experiments were made in five replications.

(5) Choice test-comparison O. melanopus male and female feeding on plants provided with EM and BA (wheat previously injured or not).
In pots were plants previously injured or uninjured by pests. For the remainder, see (4).

\section{Statistical analysis}

The results were subjected to an analysis of variance (ANOVA) in a completely random system using the program Statistica 2013. The results was previously log transformed. Normal distribution of date in individual groups was confirmed by the Shapiro-Wilk test. The significance of the differences between the object averages were estimated based on Tukey's test at the significance level $p<0.05$. The results of all no-choice and choice tests are expressed as arithmetic mean plus or minus standard deviation $( \pm S D)$. Additionally, the Pearson's correlation coefficient was measured to determine the relationship between free phenolic acids produced by winter wheat plants and $O$. melanopus feeding and development in no-choice test, with the level of significance was set at $* p<0.1, * * p<0.05, * * * p<0.01$.

\section{Results}

\section{Free phenolic acids production in plants provided with EM and BA (wheat previously injured or not)}

The winter wheat plants contained, on average, $0.172 \% \mathrm{DM}$ of free phenolic acids (Table 2). The plants exposed to EM and BA usually showed more free phenolic acids as compared to the control plants (without preparations). By far the highest contents of free phenolic acids in wheat plants were recorded for the combination in which EM was introduced into the soil during post-harvest tillage (autumn) and
Table 2 Effect of the application of EM and BA on free phenolic acids production in wheat (previously injured or not) $[\% \mathrm{DM}]$

\begin{tabular}{|c|c|c|c|}
\hline \multirow{2}{*}{$\begin{array}{l}\text { I-Pro-ecological proce- } \\
\text { dures }\end{array}$} & \multicolumn{2}{|l|}{ II-Wheat previously } & \multirow[t]{2}{*}{ Mean } \\
\hline & Uninjured & Injured & \\
\hline $1 \times \mathrm{EM}+1 \times \mathrm{BA}$ & $a 0.168 \pm 0.007 \mathrm{~b}$ & $b 0.127 \pm 0.018 \mathrm{~d}$ & $0.148 \pm 0.026 \mathrm{CD}$ \\
\hline $1 \times \mathrm{EM}+2 \times \mathrm{BA}$ & $0.157 \pm 0.008 b c$ & $0.157 \pm 0.017 \mathrm{c}$ & $0.157 \pm 0.012 \mathrm{BC}$ \\
\hline $1 \times \mathrm{EM}+0 \times \mathrm{BA}$ & $0.168 \pm 0.005 b$ & $0.160 \pm 0.002 \mathrm{c}$ & $0.164 \pm 0.005 \mathrm{~B}$ \\
\hline $2 \times \mathrm{EM}+1 \times \mathrm{BA}$ & $b 0.247 \pm 0.010 \mathrm{a}$ & $a 0.265 \pm 0.029 \mathrm{a}$ & $0.256 \pm 0.023 \mathrm{~A}$ \\
\hline $2 \times \mathrm{EM}+2 \times \mathrm{BA}$ & $0.163 \pm 0.008 b c$ & $0.163 \pm 0.007 \mathrm{c}$ & $0.163 \pm 0.007 \mathrm{BC}$ \\
\hline $2 \times \mathrm{EM}+0 \times \mathrm{BA}$ & $a 0.260 \pm 0.010 \mathrm{a}$ & $b 0.227 \pm 0.010 \mathrm{~b}$ & $0.244 \pm 0.020 \mathrm{~A}$ \\
\hline $0 \times \mathrm{EM}+1 \times \mathrm{BA}$ & $0.162 \pm 0.017 b c$ & $0.167 \pm 0.008 c$ & $0.165 \pm 0.007 \mathrm{~B}$ \\
\hline $0 \times \mathrm{EM}+2 \times \mathrm{BA}$ & $b 0.102 \pm 0.007 \mathrm{~d}$ & $a 0.132 \pm 0.004 \mathrm{~d}$ & $0.117 \pm 0.017 \mathrm{E}$ \\
\hline $0 \times \mathrm{EM}+0 \times \mathrm{BA}$ & $0.142 \pm 0.012 \mathrm{c}$ & $0.133 \pm 0.011 \mathrm{~d}$ & $0.138 \pm 0.012 \mathrm{D}$ \\
\hline Mean & $0.174 \pm 0.049$ & $0.170 \pm 0.046$ & $0.172 \pm 0.047$ \\
\hline
\end{tabular}




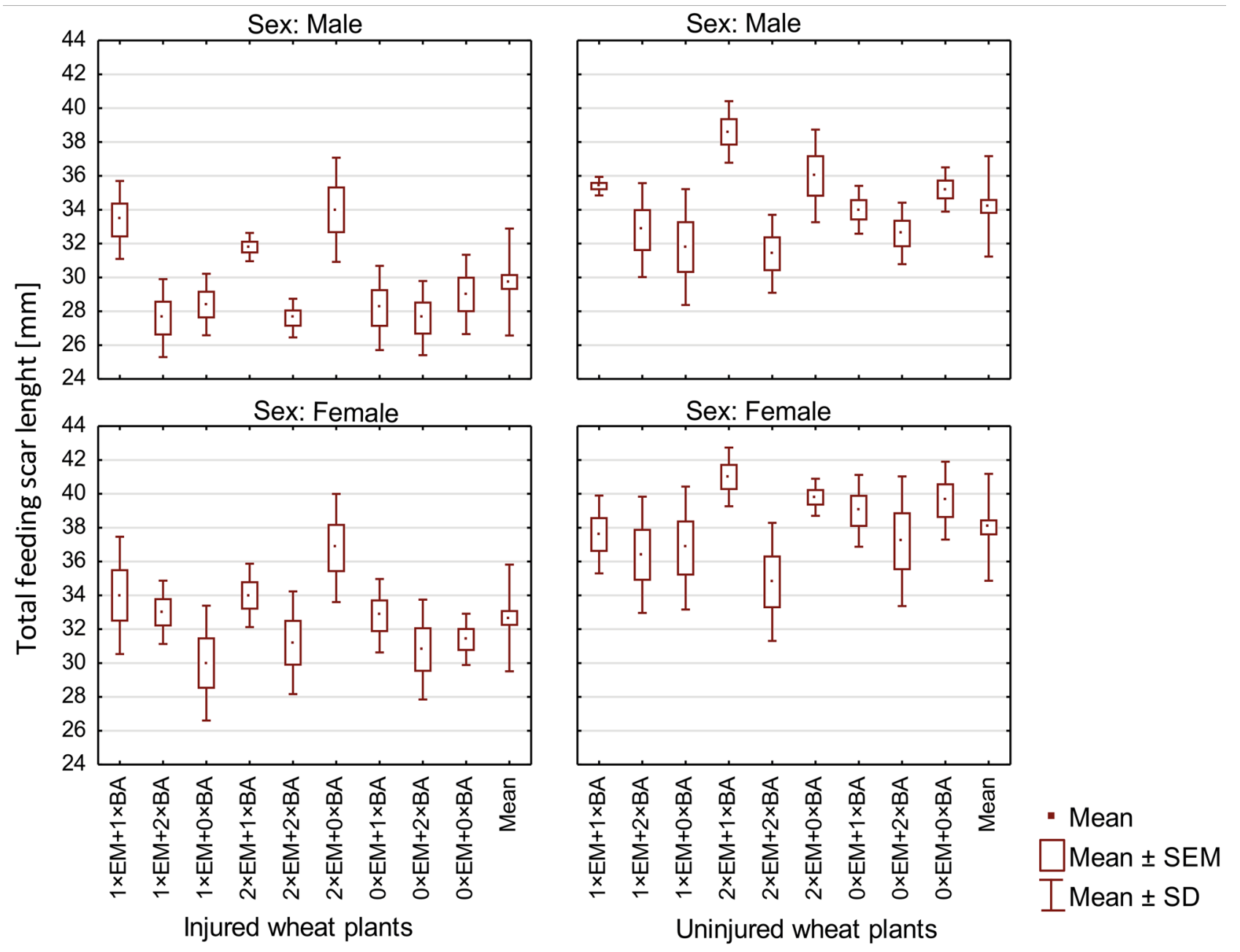

Fig. 1 Effect of the application of EM and BA in wheat previously injured or not on O. melanopus total feeding scar length (no-choice test) [mm]. SEM standard error of the mean, $S D$ standard deviation, $E M$ effective microorganisms, $B A$ biostimulant Asahi SL

was applied to leaves, and BA was applied to leaves once $(2 \times \mathrm{EM}+1 \times \mathrm{BA})$, as well as for the combination without BA $(2 \times \mathrm{EM}+0 \times \mathrm{BA}): 0.256$ and $0.244 \% \mathrm{DM}$, respectively. The lowest amounts of free phenolic acids were recorded when EM was not applied at all and BA was applied to leaves twice $(0 \times \mathrm{EM}+2 \times \mathrm{BA})$ and in control combination $(0 \times \mathrm{EM}+0 \times \mathrm{BA}): 0.117$ and $0.138 \% \mathrm{DM}$, respectively. With the calculations it was also found that the period of 2 days is too short for the plants to produce significantly different amounts of free phenolic acids. A value of $0.170 \%$ DM was received for the plants injured beforehand by O. melanopus and $0.174 \% \mathrm{DM}$ for the plants previously uninjured.

\section{O. melanopus male and female feeding on plants provided with EM and BA (wheat previously injured or not, no-choice test)}

Irrespective of insect sex, uninjured plants were fed upon more intensively than previously injured plants (36.11 vs $31.20 \mathrm{~mm}$ feeding scar length). Interestingly, irrespective of whether the plants had been injured or were uninjured, it was always the females that caused greater leaf area losses than the males of that insect species: 32.67 and $38.02 \mathrm{~mm}$ for females and 29.73 and $34.20 \mathrm{~mm}$ for males, respectively (Fig. 1). The coefficients of correlation obtained ( $r=0.678$ for $\alpha=0.05$ ) showed that the content of free phenolic acids in winter wheat plants affect the feeding of Oulema spp., and that for females this effect is bigger on plants previously uninjured by pests but for male cereal leaf beetles it is similar on those plants previously injured by pests and those not (respectively: 0.584 and 0.567 ) (Table 3 ). 
Table 3 Pearson's correlation coefficients $(r)$ between free phenolic acids produced by wheat and $O$. melanopus feeding and development (no-choice test)

\begin{tabular}{lcl}
\hline O. melanopus & \multicolumn{2}{l}{$\begin{array}{l}\text { Free phenolic acids in wheat previ- } \\
\text { ously }\end{array}$} \\
\cline { 2 - 3 } & Uninjured & Injured \\
\hline Female feeding & $0.678^{* *}$ & 0.466 \\
Male feeding & $0.567^{*}$ & $0.584^{* *}$ \\
Oviposition & 0.428 & - \\
Eggs duration & 0.062 & - \\
Larvae hatching & -0.016 & - \\
\hline
\end{tabular}

$n=10$

$* * * r_{\text {crit. }} 0.01=0.708$

$* * r_{\text {crit. }}{ }^{0.05}=0.576$

$* r_{\text {crit. }} 0.1=0.497$

\section{O. melanopus development on plants provided with EM and BA (wheat previously uninjured, no-choice test)}

We found that on wheat plants previously uninjured by pests, the application of EM and BA, does not reduce-egg laying by $O$. melanopus females, does not adversely affect embryogenesis length, and does not reduce hatching $\mathrm{L}_{1}$ as compared with control (without preparations application) - statistically non-significant differences (Fig. 2). The obtained coefficients of correlation showed that in no-choice test, the content of free phenolic acids in winter wheat plants did not affect the development of $O$. melanopus, i.e. oviposition, eggs duration and larvae hatching (Table 3 ).

\section{Comparison in choice test, 0 . melanopus male and female feeding on plants provided with EM and BA or not (wheat previously uninjured)}

In this part of our work, all plants were previously uninjured by pests, and $O$. melanopus females and males could choose between plants provided with EM and BA or not to feed on them. We found that females of cereal leaf beetle reduced the leaf area more than did males: $27.07 \mathrm{~mm}$ (plants untreated with preparations) and $12.13 \mathrm{~mm}$ (plants treated with preparations) and $24.04 \mathrm{~mm}$ (plants untreated with preparations) and $10.82 \mathrm{~mm}$ (plants treated with preparations), respectively (Table 4). The total feeding scar length, both $O$. melanopus females and males, was bigger for wheat plants untreated by preparations, as compared with plants provided with EM and BA (in all cases $p<0.001$ ). Only with the combination $0 \times \mathrm{EM}+0 \times \mathrm{BA}$ (for both females and males, and for plants treated by preparations and those not) did we obtain similar total feeding scar lengths: from 16.80 to $19.40 \mathrm{~mm}$ (Table 4).

\section{Comparison in choice test, 0 . melanopus male and female feeding on plants provided with EM and BA (wheat previously injured or not)}

We investigated the difference for females and males of cereal leaf beetle in the total feeding scar length when they could choose food between plants previously uninjured by pests or those previously injured (Table 5). We showed that on winter wheat plants previously uninjured by pests, the total feeding scar length by $O$. melanopus female is more, as compared with the male: $31.87 \mathrm{~mm}$ and $27.07 \mathrm{~mm}$, respectively. However, in the case of plants previously injured by pests, the opposite situation was observed: $5.11 \mathrm{~mm}$ (female) and $6.98 \mathrm{~mm}$ (male). Both female and male of cereal leaf beetle much more prefer winter wheat plants previously uninjured by pests, as compared with previously injured plants.

\section{Discussion}

Modern plant protection requires many activities on the part of humans. It is best if they are in harmony with nature. These can be non-chemical methods of supporting plants in reducing pest numbers (Van Bueren et al. 2011; Birkhofer et al. 2016; Lemanowicz et al. 2020; Szczepanek et al. 2020).

In our research, the EM and BA influenced winter wheat plants and its pest $O$. melanopus. It was noticed that winter wheat plants treated with these pro-ecological procedures generally released more free phenolic acids than untreated plants. Similarly, in other studies where the same combination of preparations was tested, the winter wheat plants provided with EM and BA released more total content of phenolic compounds converted into pyrogallol, as compared with plants untreated by these preparations (Lamparski et al. 2015). In contrast, in the case of content of flavonoids (expressed as the amount of quercetin), the application of EM and BA did not differentiate the release of these secondary metabolite compounds by winter wheat plants as compared with untreated plants (Lamparski et al. 2017). The results of all these studies show that treated winter wheat plants provided with EM and BA correspond to an increase in the production of phenolic compounds - these important secondary metabolite compounds. Yakhin et al. (2017) writes that modern biostimulants are complex mixtures derived from raw materials of highly diverse origin and utilizing highly diverse manufacturing processes and, as such, can be expected to have a broad spectrum of possible biological activity and safety. Likewise, Torre et al. (2013) claims that biostimulants protect plants against pests.

In our own research it was noticed that plants treated with preparations and previously uninjured by pests emit similar 
Fig. 2 Effect of the application of EM and BA in wheat previously uninjured on $O$. melanopus development (no-choice test). Results are expressed as arithmetic mean $\pm \mathrm{SD}$. $\mathrm{HSD}_{0.05}$ for oviposition (A), eggs duration $(\mathbf{B})$ and larvae hatching (C) —not significant. $E M$ effective microorganisms, $B A$ biostimulant Asahi SL

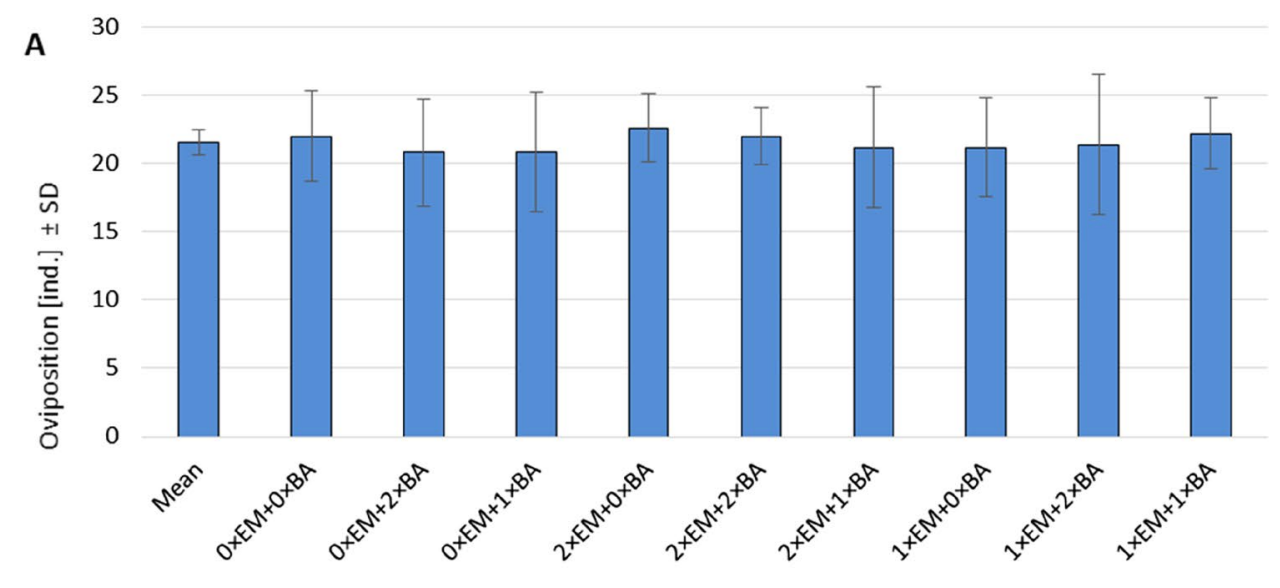

B
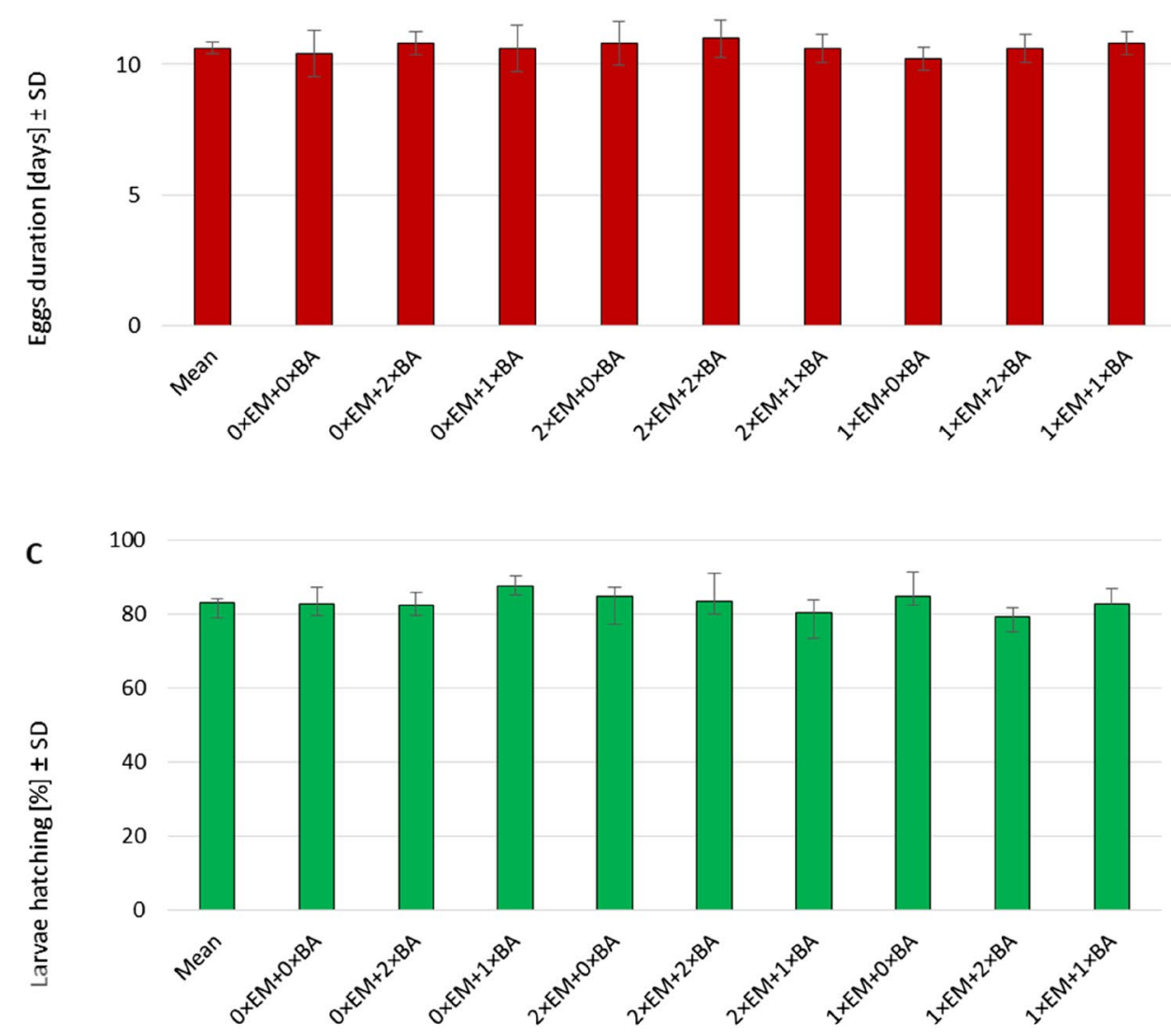

amounts of free phenolic acids (expressed as caffeic acid) as compared with plants treated with preparations and previously injured by pests (respectively: $0.174 \%$ DM for wheat previously uninjured and $0.170 \% \mathrm{DM}$ for those injured beforehand). In other studies, the differences were more visible. As reported (Lamparski et al. 2015, 2017), winter wheat plants produced larger amounts of other phenolic compounds-flavonoids (expressed as the amount of quercetin) and total content of phenolic compounds (converted into pyrogallol)—when these plants have been provided with EM and BA and previously uninjured by pests, as compared with plants that have been provided with EM and BA and have previously been injured by pests. Plants, of course, do not always respond to injury by increasing production of all secondary metabolism compounds. Piesik et al. (2010a) reported that mechanical injury and injury caused by feeding of adults of leaf beetle (Oulema spp.) increased the release of VOCs by wheat, barley and millet plants. The level of the 
Table 4 Comparison in choice test, $O$. melanopus male and female feeding on wheat provided with EM and BA or not (plants previously uninjured) $[\mathrm{mm}]$

\begin{tabular}{|c|c|c|c|c|}
\hline \multicolumn{2}{|c|}{ Plants treated by preparations } & \multicolumn{2}{|c|}{ Plants untreated by preparations } & \multirow[t]{2}{*}{ HSD } \\
\hline \multicolumn{4}{|l|}{ O. melanopus male } & \\
\hline $1 \times \mathrm{EM}+1 \times \mathrm{BA}$ & $8.60 \pm 1.673$ & $0 \times \mathrm{EM}+0 \times \mathrm{BA}$ & $25.40 \pm 1.817$ & $2.546 * * *$ \\
\hline $1 \times \mathrm{EM}+2 \times \mathrm{BA}$ & $9.00 \pm 1.581$ & $0 \times \mathrm{EM}+0 \times \mathrm{BA}$ & $24.80 \pm 0.447$ & $1.695 * * *$ \\
\hline $1 \times \mathrm{EM}+0 \times \mathrm{BA}$ & $9.20 \pm 1.789$ & $0 \times \mathrm{EM}+0 \times \mathrm{BA}$ & $22.60 \pm 2.608$ & $3.260 * * *$ \\
\hline $2 \times \mathrm{EM}+1 \times \mathrm{BA}$ & $12.40 \pm 1.673$ & $0 \times \mathrm{EM}+0 \times \mathrm{BA}$ & $26.40 \pm 3.782$ & $4.263 * * *$ \\
\hline $2 \times \mathrm{EM}+2 \times \mathrm{BA}$ & $10.20 \pm 2.168$ & $0 \times \mathrm{EM}+0 \times \mathrm{BA}$ & $25.40 \pm 2.881$ & $3.717 * * *$ \\
\hline $2 \times \mathrm{EM}+0 \times \mathrm{BA}$ & $10.80 \pm 0.837$ & $0 \times \mathrm{EM}+0 \times \mathrm{BA}$ & $26.20 \pm 4.868$ & $5.092 * * *$ \\
\hline $0 \times \mathrm{EM}+1 \times \mathrm{BA}$ & $9.00 \pm 1.414$ & $0 \times \mathrm{EM}+0 \times \mathrm{BA}$ & $24.20 \pm 3.962$ & $4.337 * * *$ \\
\hline $0 \times \mathrm{EM}+2 \times \mathrm{BA}$ & $10.20 \pm 0.447$ & $0 \times \mathrm{EM}+0 \times \mathrm{BA}$ & $24.60 \pm 2.702$ & $2.823 * * *$ \\
\hline $0 \times \mathrm{EM}+0 \times \mathrm{BA}$ & $18.00 \pm 2.121$ & $0 \times \mathrm{EM}+0 \times \mathrm{BA}$ & $16.80 \pm 1.643$ & $2.766 \mathrm{~ns}$ \\
\hline Mean & $10.82 \pm 0.811$ & Mean & $24.04 \pm 0.564$ & $1.021 * * *$ \\
\hline \multicolumn{5}{|l|}{ O. melanopus female } \\
\hline $1 \times \mathrm{EM}+1 \times \mathrm{BA}$ & $11.00 \pm 2.449$ & $0 \times \mathrm{EM}+0 \times \mathrm{BA}$ & $29.20 \pm 0.837$ & $2.668 * * *$ \\
\hline $1 \times \mathrm{EM}+2 \times \mathrm{BA}$ & $10.20 \pm 1.924$ & $0 \times \mathrm{EM}+0 \times \mathrm{BA}$ & $26.60 \pm 2.191$ & $3.006 * * *$ \\
\hline $1 \times \mathrm{EM}+0 \times \mathrm{BA}$ & $10.40 \pm 1.517$ & $0 \times \mathrm{EM}+0 \times \mathrm{BA}$ & $28.80 \pm 1.924$ & $2.525 * * *$ \\
\hline $2 \times \mathrm{EM}+1 \times \mathrm{BA}$ & $12.80 \pm 1.789$ & $0 \times \mathrm{EM}+0 \times \mathrm{BA}$ & $29.40 \pm 1.517$ & $2.418 * * *$ \\
\hline $2 \times \mathrm{EM}+2 \times \mathrm{BA}$ & $10.80 \pm 1.643$ & $0 \times \mathrm{EM}+0 \times \mathrm{BA}$ & $26.80 \pm 3.114$ & $3.630 * * *$ \\
\hline $2 \times \mathrm{EM}+0 \times \mathrm{BA}$ & $11.40 \pm 0.894$ & $0 \times \mathrm{EM}+0 \times \mathrm{BA}$ & $28.80 \pm 2.387$ & $2.628 * * *$ \\
\hline $0 \times \mathrm{EM}+1 \times \mathrm{BA}$ & $11.80 \pm 1.304$ & $0 \times \mathrm{EM}+0 \times \mathrm{BA}$ & $27.60 \pm 2.074$ & $2.525 * * *$ \\
\hline $0 \times \mathrm{EM}+2 \times \mathrm{BA}$ & $11.40 \pm 1.342$ & $0 \times \mathrm{EM}+0 \times \mathrm{BA}$ & $28.20 \pm 1.095$ & $1.786 * * *$ \\
\hline $0 \times \mathrm{EM}+0 \times \mathrm{BA}$ & $19.40 \pm 1.817$ & $0 \times \mathrm{EM}+0 \times \mathrm{BA}$ & $18.20 \pm 0.837$ & $2.062 \mathrm{~ns}$ \\
\hline Mean & $12.13 \pm 0.700$ & Mean & $27.07 \pm 0.660$ & $0.993 * * *$ \\
\hline
\end{tabular}

Data (total scar length) are presented as mean \pm SD

The differences were tested using Tukey's test $n s$ not significant, $E M$ effective microorganisms, $B A$ biostimulator Asahi SL

Level of significance: $* p<0.05, * * p<0.01, * * * p<0.001$ compounds released is also affected by the neighbourhood of the injured or uninjured plants. Placed in the vicinity of plants previously injured mechanically or by insects (cereal leaf beetles) in wheat, barley and oat, the plants of uninjured cereals emitted much more of those compounds than did control plants. In other studies (Piesik et al. 2011) it has been indicated that mechanical injury to cereal crops (wheat, barley and millet) resulted in releasing several VOCs. However, after injury by Oulema spp., the cereal plants released numerous green leaf volatiles (GLV).

In our research-O. melanopus adults males and females feeding (no-choice test) - the wheat plants previously uninjured were a more attractive food for $O$. melanopus as compared with the plants previously injured. Also, irrespective of whether the wheat plants had previously been injured or not, the females always caused greater leaf area losses than the males of that insect species. $O$. melanopus adults were feeding, on average, slightly more than $30 \mathrm{~mm}$ of leaf tissue per day. As compared with our data, Lamparski (2016) found that, as for the spring barley plants, a pair of $O$. melanopus insects ate on average almost $160 \mathrm{~mm}$ of leaf tissue in 3 days of feeding (26 mm per insect per day). Clement et al. (2011) report on the leaf scar length in wild grass, Phleum alpinum, as a result of feeding of three $O$. melanopus males and three females for $24 \mathrm{~h}$ being more than $97 \mathrm{~mm}$ (16 mm per insect per day) in grasses infected by fungus of genus Neothypo$\operatorname{dium}(\mathrm{E}+)$ and in grasses free from that fungus $(\mathrm{E}-)$-more than $74 \mathrm{~mm}$ (12 $\mathrm{mm}$ per insect per day) in scar length.

In our study, in no-choice tests, cereal leaf beetle development was similar on wheat plants provided with EM and BA as on untreated plants (control). Our research performed in wheat plants resulted in 21 eggs laid (a pair of insects for 3 days), about 10 days of embryogenesis and more than $80 \%$ hatching $\mathrm{L}_{1}$. On barley plants, Lamparski (2016) found that development intensity of $O$. melanopus is similar both on plants provided with EM and BA and on those untreated by preparations. He found that in laboratory conditions, in nochoice tests with barley plants, $O$. melanopus laid 22 eggs (a pair of insects for 3 days), egg duration was 10.3 days and larva hatching was $81 \%$.

An even clearer situation was noted in choice tests. Both O. melanopus males and females much preferred plants unprovided with EM and BA than those treated with preparations. We found that the wheat previously uninjured plants 
Table 5 Comparison in choice test, $O$. melanopus male and female feeding on wheat provided with EM and BA (plants previously injured or not) $[\mathrm{mm}]$

\begin{tabular}{|c|c|c|c|c|}
\hline \multicolumn{2}{|c|}{ Previously uninjured plants } & \multicolumn{2}{|c|}{ Previously injured plants } & \multirow[t]{2}{*}{ HSD } \\
\hline \multicolumn{4}{|l|}{ O. melanopus male } & \\
\hline $1 \times \mathrm{EM}+1 \times \mathrm{BA}$ & $27.00 \pm 2.000$ & $1 \times \mathrm{EM}+1 \times \mathrm{BA}$ & $6.40 \pm 1.140$ & $2.373 * * *$ \\
\hline $1 \times \mathrm{EM}+2 \times \mathrm{BA}$ & $26.40 \pm 1.517$ & $1 \times \mathrm{EM}+2 \times \mathrm{BA}$ & $7.20 \pm 1.095$ & $1.929 * * *$ \\
\hline $1 \times \mathrm{EM}+0 \times \mathrm{BA}$ & $25.20 \pm 2.775$ & $1 \times \mathrm{EM}+0 \times \mathrm{BA}$ & $6.20 \pm 1.789$ & $3.404 * * *$ \\
\hline $2 \times \mathrm{EM}+1 \times \mathrm{BA}$ & $29.20 \pm 0.837$ & $2 \times \mathrm{EM}+1 \times \mathrm{BA}$ & $5.60 \pm 0.894$ & $1.263 * * *$ \\
\hline $2 \times \mathrm{EM}+2 \times \mathrm{BA}$ & $25.20 \pm 1.789$ & $2 \times \mathrm{EM}+2 \times \mathrm{BA}$ & $6.80 \pm 1.095$ & $2.162 * * *$ \\
\hline $2 \times \mathrm{EM}+0 \times \mathrm{BA}$ & $27.40 \pm 1.517$ & $2 \times \mathrm{EM}+0 \times \mathrm{BA}$ & $6.20 \pm 0.447$ & $1.630 * * *$ \\
\hline $0 \times \mathrm{EM}+1 \times \mathrm{BA}$ & $28.00 \pm 1.871$ & $0 \times \mathrm{EM}+1 \times \mathrm{BA}$ & $8.40 \pm 0.894$ & $2.138 * * *$ \\
\hline $0 \times \mathrm{EM}+2 \times \mathrm{BA}$ & $26.00 \pm 1.225$ & $0 \times \mathrm{EM}+2 \times \mathrm{BA}$ & $7.60 \pm 0.894$ & $1.563 * * *$ \\
\hline $0 \times \mathrm{EM}+0 \times \mathrm{BA}$ & $29.20 \pm 1.924$ & $0 \times \mathrm{EM}+0 \times \mathrm{BA}$ & $8.40 \pm 0.548$ & $2.062 * * *$ \\
\hline Mean & $27.07 \pm 0.688$ & Mean & $6.98 \pm 0.241$ & $0.750 * * *$ \\
\hline \multicolumn{5}{|c|}{ O. melanopus female } \\
\hline $1 \times \mathrm{EM}+1 \times \mathrm{BA}$ & $31.80 \pm 3.114$ & $1 \times \mathrm{EM}+1 \times \mathrm{BA}$ & $5.20 \pm 0.837$ & $3.325 * * *$ \\
\hline $1 \times \mathrm{EM}+2 \times \mathrm{BA}$ & $31.00 \pm 2.828$ & $1 \times \mathrm{EM}+2 \times \mathrm{BA}$ & $5.20 \pm 1.095$ & $3.127 * * *$ \\
\hline $1 \times \mathrm{EM}+0 \times \mathrm{BA}$ & $30.40 \pm 2.608$ & $1 \times \mathrm{EM}+0 \times \mathrm{BA}$ & $3.60 \pm 1.342$ & $3.023 * * *$ \\
\hline $2 \times \mathrm{EM}+1 \times \mathrm{BA}$ & $32.60 \pm 3.578$ & $2 \times \mathrm{EM}+1 \times \mathrm{BA}$ & $5.80 \pm 1.095$ & $3.857 * * *$ \\
\hline $2 \times \mathrm{EM}+2 \times \mathrm{BA}$ & $30.40 \pm 1.517$ & $2 \times \mathrm{EM}+2 \times \mathrm{BA}$ & $6.20 \pm 0.837$ & $1.178 * * *$ \\
\hline $2 \times \mathrm{EM}+0 \times \mathrm{BA}$ & $33.80 \pm 2.950$ & $2 \times \mathrm{EM}+0 \times \mathrm{BA}$ & $5.40 \pm 0.548$ & $3.093 * * *$ \\
\hline $0 \times \mathrm{EM}+1 \times \mathrm{BA}$ & $33.80 \pm 1.095$ & $0 \times \mathrm{EM}+1 \times \mathrm{BA}$ & $5.60 \pm 0.894$ & $1.458 * * *$ \\
\hline $0 \times \mathrm{EM}+2 \times \mathrm{BA}$ & $30.60 \pm 3.362$ & $0 \times \mathrm{EM}+2 \times \mathrm{BA}$ & $5.00 \pm 1.732$ & $3.898 * * *$ \\
\hline $0 \times \mathrm{EM}+0 \times \mathrm{BA}$ & $32.40 \pm 1.817$ & $0 \times \mathrm{EM}+0 \times \mathrm{BA}$ & $4.00 \pm 1.000$ & $2.138 * * *$ \\
\hline Mean & $31.87 \pm 1.126$ & Mean & $5.11 \pm 0.437$ & $1.248 * * *$ \\
\hline
\end{tabular}

Data (total scar length) are presented as mean $\pm \mathrm{SD}$

The differences were tested using Tukey's test $n s$ not significant, $E M$ effective microorganisms, $B A$ biostimulant Asahi SL Level of significance: $* p<0.05, * * p<0.01$, *** $p<0.001$ were much more attractive for O. melanopus as compared with the previously injured plants. Thus, healthy (uninjured) plants are preferred as food by pests (Piesik et al. 2010a, 2011).

The results of our research and other authors indicate that the choice of food by cereal leaf beetles is greatly influenced by the secondary metabolism compounds produced and emitted by plants. These compounds attract or repel females and males of cereal leaf beetle (Piesik et al. 2010b). One of the most active groups of so-called allelo compounds that participates in the environmental effects is phenolic compounds. They are common in plant tissues, and even at low concentrations can have a toxic effect on entomophage (Li et al. 2010). Phenolic acids usually occur in bonds with other compounds but also in acid environments, after heating a hydrolysis of ester and glycosidic bonds can take place, which increases the amount of free phenolic acids (released from bonds), so we are talking about free phenolic acids (Lege et al. 1995; Dykes and Rooney 2007; Jeszka et al. 2010). Free phenolic acids are the most significant factors in resistance mechanisms as the first line of defense together with their antioxidant action (Stuper-Szablewska et al. 2019). It is known that antioxidative reactions are activated in the case of plant infection (Gupta and Sharma 2006; Kasote et al. 2015; Działo et al 2016; Kulbat 2016). GawlikDziki (2004) found that free phenolic acids usually occur in small amounts and their content greatly depends on the species and plant maturity. Wheat plants exposed to biotic stress contained the greatest amounts of free phenolic acids (Stuper-Szablewska et al. 2019). Free phenolic acids play a significant role in plant resistance mechanisms irrespective of the type of stress factors (Mandal et al. 2010).

The results of our research show that the use of EM and BA on winter wheat plants, makes it possible to introduce these treatments to field production as an important alternative to the use of chemical plant protection products. Thus, we are in line with the current trend of agricultural biologization, i.e., replacing chemical methods with more environmentally friendly ones.

Funding The National Science Center, Poland (Grant no. PB-7295/B/ P01/2011/40). 
Open Access This article is licensed under a Creative Commons Attribution 4.0 International License, which permits use, sharing, adaptation, distribution and reproduction in any medium or format, as long as you give appropriate credit to the original author(s) and the source, provide a link to the Creative Commons licence, and indicate if changes were made. The images or other third party material in this article are included in the article's Creative Commons licence, unless indicated otherwise in a credit line to the material. If material is not included in the article's Creative Commons licence and your intended use is not permitted by statutory regulation or exceeds the permitted use, you will need to obtain permission directly from the copyright holder. To view a copy of this licence, visit http://creativecommons.org/licenses/by/4.0/.

\section{References}

Bennett RN, Wallsgrove RM (1994) Secondary metabolites in plant defence mechanisms. New Phytol 127:617-633

Birkhofer K, Arvidsson F, Ehlers D, Mader VL, Bengtsson J, Smith HG (2016) Organic farming affects the biological control of hemipteran pests and yields in spring barley independent of landscape complexity. Landscape Ecol 31:567-579

Breinholt V (1999) Desirable versus harmful levels of intake of flavonoids and phenolic acids. In: Kumpulainen JT, Salonen JT (eds) Natural antioxidants and anticarcinogens in nutrition, health and disease. The Royal Society of Chemistry, Elsevier, Hoboken, pp 93-105

Černy I, Pačuta V, Fecková J, Golian J (2002) Effect of year and Atonic application of the selected sugar beet production and quality parameters. J Central Europ Agric 3:15-21

Ciepiela AP, Chrzanowski G (2000) Polyphenolic compounds of winter triticale leaves. Herba Pol 46:278-282

Cipollini D, Stevenson R, Enright S, Eyles A, Bonello P (2008) Phenolic metabolites in leaves of the invasive shrub, Lonicera maackii, and their potential phytotoxic and anti-herbivore effects. J Chem Ecol 34:144-152

Clement SL, Hu J, Stewart AV, Wang B, Elberson LR (2011) Detrimental and neutral effects of a wild grass-fungal endophyte symbiotum on insect preference and performance. J Insect Sci 11:1-13

Czeczko R, Mikos-Bielak M (2004) Effects of Asahi bio-stimulator application in the cultivation of different vegetable species. Ann UMCS Agric 59:1073-1079

Douglas AE (2007) Symbiotic microorganisms: untapped resources for insect pest control. Trends Biotechnol 25:338-342

Dykes L, Rooney LW (2007) Phenolic compounds in cereal grains and their health benefits. Cereal Food World 52:105-111

Działo M, Mierziak J, Korzun U, Preisner M, Szopa J, Kulma A (2016) The potential of plant phenolics in prevention and therapy of skin disorders. Int J Mol Sci 17(2):160

Dzienia S, Zimny L, Weber R (2006) The newest trends in soil tillage and techniques of sowing. Fragm Agron 23:227-241

Gawlik-Dziki U (2004) Phenolic acids as bioactive compounds in food products. Zywn-Nauk Technol Ja 4:29-40

Gupta VK, Sharma SK (2006) Plants as natural antioxidants. Nat Prod $\operatorname{Rad} 5(4): 326-334$

Harasimowicz-Hermann G, Borowska M (2006) Effect of bio-stimulant Asahi SL in winter rapeseed depending on pluviothermic conditions. Oilseed Crops 27:95-106

Harborne J (1997) Biochemical ecology. PWN, Warszawa, p 351

Janas R (2009) Possibilities of using effective microorganisms in organic production systems of cultivated crops. Probl Inż Rol 3:111-119

Javaid A, Bajwa R (2011) Field evaluation of effective microorganisms (EM) application for growth, nodulation, and nutrition of mung bean. Turk J Agric for 35:443-452
Javaid A, Shah MBM (2010) Growth and yield response of wheat to EM (effective microorganisms) and parthenium green manure. Afr J Biotechnol 9:3373-3381

Jeszka M, Flaczek E, Kobus-Cisowska J, Dziedzic K (2010) Phenolics-characteristic and significance in food technology. Nauka Przyr Technol 4:1-13

Kaczmarek Z, Wolna-Maruwka A, Jakubus M (2008) Changes of the number of selected microorganism groups and enzymatic activity in the soil inoculated with effective microorganisms (EM). J Res Appl Agric Eng 53:122-127

Kaniuczak Z, Bereś P (2008) The most harmful cereals pests in ecological farms of south-east Poland. J Res Appl Agric Eng $53: 128-132$

Kasote DM, Katyare SS, Hegde MV, Bae H (2015) Significance of antioxidant potential of plants and its relevance to therapeutic applications. Int J Biol Sci 11(8):982-991

Klepacka J, Fornal Ł (2006) Bioactive components of buckwheat and its prohealth function (review article). Fragm Agron 1:78-92

Klepacka J, Fornal $Ł$ (2008) Research into correlations between the content of some selected phenolic compounds and the milling quality of wheat grain. Zywn-Nauk Technol Ja 6:55-64

Kotwica K, Jaskulska I, Jaskulski D, Gałęzewski L, Walczak D (2011) Effect of nitrogen fertilisation and the method of soil fertilisation on winter wheat yielding depending on the previous crop. Fragm Agron 28:53-62

Kulbat K (2016) The role of phenolic compounds in plant resistance. Biotechnol Food Sci 80:97-108

Lamparski R (2016) Entomological and biochemical effects of the application of pro-ecological agrotechnical treatments in spring barley. University of Toronto Press, Bydgoszcz, p 106

Lamparski R (2020) The effects of effective microorganisms, a biostimulant and the treatment method of forecrop straw on hemimetabolous herbivores in winter wheat. Acta Sci Pol Agricultura 19(2):107-117

Lamparski R, Balcerek M, Modnicki D, Kotwica K, Wawrzyniak M (2015) The effect of pro-ecological procedures and insect foraging on the total content of phenol compounds in winter wheat. Acta Biol Hung 66:169-178

Lamparski R, Modnicki D, Balcerek M, Kotwica K, Jaskulska I, Wawrzyniak M (2017) Effects of effective microorganisms and biostimulator on flavonoids in winter wheat and Oulema melanopus. Allelopathy J 42:135-144

Lege KE, Cothren JT, Smith CW (1995) Phenolic acid and condensed tannin concentration of six cotton genotypes. Enwir Exper Bot 35:241-249

Lemanowicz J, Bartkowiak A, Lamparski R, Wojewódzki P, Pobereżny J, Wszelaczyńska E, Szczepanek M (2020) Physicochemical and enzymatic soil properties influenced by cropping of primary wheat (Triticum sphaerococcum and Triticum persicum) under organic and conventional farming systems. Agronomy 10:1652

Leszczyński B (2010) Selected aspects of biochemistry and toxicology of the environment. Academic Press, Siedlce, p 173

Li ZH, Wang Q, Ruan X, Pan CD, Jiang DA (2010) Phenolics and plant allelopathy. Molecules 15:8933-8952

Maciejewski T, Szukała J, Jarosz A (2007) Influence of biostymulator Asahi SL and Atonik SL on qualitative tubers of potatoes. J Res Appl Agric Eng 52:109-112

Malinowski H (2008) Defensive strategies of woody plants against harmful insects. For Res Pap 69:165-173

Mallikarjuna N, Kranthi KR, Jadhav DR, Kranthi S, Chandra S (2004) Influence of foliar chemical compounds on the development of Spodoptera litura (Fab.) in interspecific derivatives of groundnut. J Appl Entomol 128:321-328 
Mandal SM, Chakraborty D, Dey S (2010) Phenolic acids act as signaling molecules in plant-microbe symbioses. Plant Signal Behav 5(4):359-368

Matysiak K, Adamczewski K, Kaczmarek S (2011) Response of some crops cultivated in great Poland to application of Asahi SL. Prog Plant Prot 51:1849-1857

Megali L, Schlau B, Rasmann S (2015) Soil microbial inoculation increases corn yield and insect attack. Agron Sustain Dev 35:1511-1519

Michalski T, Horoszkiewicz-Janka J (2005) The effect of biopreparation Asahi SL on healthiness and yielding of barley and spring wheat. Prog Plant Prot 45:910-913

Mróz P, Wilczek K, Żak M, Zielińska-Pisklak M (2012) Chromatographic methods of isolation and identification of phenolic acids. Biul Wydz Farm WUM 6:40-48

Okorski A, Majchrzak B (2008) Fungi colonizing pea seeds after using of microbiological control product EM 1. Prog Plant Prot 48:1314-1318

Pharmacopoeia Polonica IX (2011) Polskie Towarzystwo Farmakologiczne, Warszawa, p. 1176 (In Polish)

Philips CR, Herbert DA, Kuhar TP, Reisig DD, Thomason WE, Malone S (2011) Fifty years of cereal leaf beetle in the US: an update on its biology, management, and current research. J Int Pest Manag $2: 1-5$

Piesik D, Łyszczarz A, Tabaka P, Lamparski R, Bocianowski J, Delaney KJ (2010a) Volatile induction of three cereals: influence of mechanical injury and insect herbivory on injured plants and neighboring uninjured plants. Ann Appl Biol 157:425-434

Piesik D, Wenda-Piesik A, Lamparski R, Tabaka P, Ligor T, Buszewski B (2010b) Effects of mechanical injury and insect feeding on volatiles emitted by wheat plants. Entomol Fennica 21:117-128

Piesik D, Pańka D, Delaney KJ, Skoczek A, Lamparski R, Weaver DK (2011) Cereal crop volatile organic compound induction after mechanical injury, beetle herbivory (Oulema spp.), or fungal infection (Fusarium spp.). J Plant Physiol 168:878-886
Piskier T (2006) Reaction of spring wheat to the application of biostimulators and soil absorbents. J Res Appl Agric Eng 51:136-138

Rashid M, Chung YR (2017) Induction of systemic resistance against insect herbivores in plants by beneficial soil microbes. Front Plant Sci 8:1816

Shi LE, Zhang ZL, Xing LY, Yang DD, Guo YP, Guo XF, Zhao LM, Tang ZX (2011) Antioxidants extraction by supercritical $\mathrm{CO}_{2}$. J Med Plants Res 5:300-308

Smith CM, Boyko EV (2007) The molecular bases of plant resistance and defense responses to aphid feeding: current status. Entomol Exp Appl 122:1-16

Stuper-Szablewska K, Kurasiak-Popowska D, Nawracała J, Perkowski J (2019) Quantitative profile of phenolic acids and antioxidant activity of wheat grain exposed to stress. Eur Food Res Technol 245:1595-1603

Szczepanek M, Lemańczyk G, Lamparski R, Wilczewski E, Graczyk R, Nowak R, Prus P (2020) Ancient wheat species (Triticum sphaerococcum Perc. and T. persicum Vav.) in organic farming: influence of sowing density on agronomic traits, pests and diseases occurrence, and weed infestation. Agriculture 10(11):556

Torre LA, Battaglia V, Caradonia F (2013) Legal aspects of the use of plants trengtheners (biostimulants) in Europe. Bulg J Agric Sci 19:1183-1189

Truba M, Jankowski K, Sosnowski J (2012) The plants reactions on biological preparations treatment. Ochr Środ Zasob Natur 53:41-52

Van Bueren EL, Jones SS, Tamm L, Murphy KM, Myers JR, Leifert C, Messmer MM (2011) The need to breed crop varieties suitable for organic farming, using wheat, tomato and broccoli as examples: a review. NJAS-Wagen J Life Sc 58:193-205

Yakhin OI, Lubyanov AA, Yakhin IA, Brown PH (2017) Biostimulants in plant science: a global perspective. Front Plant Sci 7:2049

Publisher's Note Springer Nature remains neutral with regard to jurisdictional claims in published maps and institutional affiliations.

\section{Authors and Affiliations}

\section{Robert Lamparski $^{1}$ (I) $\cdot$ Karol Kotwica $^{2} \cdot$ Daniel Modnicki $^{3} \cdot$ Maciej Balcerek $^{3} \cdot$ Beata Koim-Puchowska $^{4}$}

Karol Kotwica

kotwica@pbs.edu.pl

Daniel Modnicki

dmodnicki@cm.umk.pl

Maciej Balcerek

balcerek@cm.umk.pl

Beata Koim-Puchowska

koimpuchowska@ukw.edu.pl

1 Department of Biology and Plant Protection, Bydgoszcz

University of Science and Technology, Kaliskiego 7, 85-796 Bydgoszcz, Poland
2 Department of Agrotechnology, Bydgoszcz University of Science and Technology, Kaliskiego 7, 85-796 Bydgoszcz, Poland

3 Chair of Pharmacognosy, Nicolaus Copernicus University, Collegium Medicum, Skłodowskiej-Curie 9, 85-094 Bydgoszcz, Poland

4 Department of Biotechnology, Kazimierz Wielki University, Poniatowskiego 12, 85-671 Bydgoszcz, Poland 